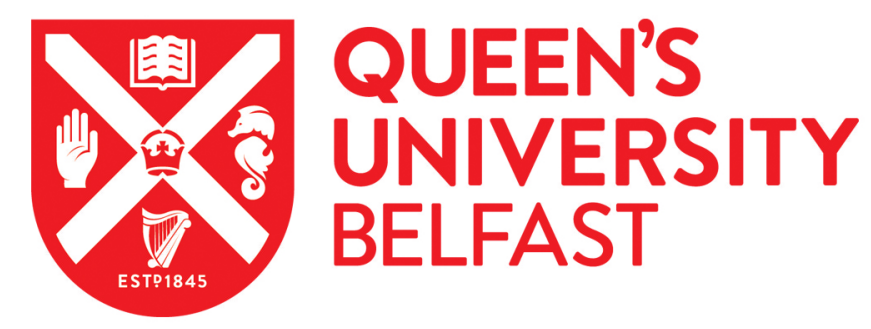

\title{
Book Review: State Crime on the Margins of Empire: Rio Tinto, the War on Bougainville and Resistance to Mining, by Kristian Lasslett
}

Thomson, A. (2015). Book Review: State Crime on the Margins of Empire: Rio Tinto, the War on Bougainville and Resistance to Mining, by Kristian Lasslett. Critical Studies on Terrorism, 8(3), 548-551.

https://doi.org/10.1080/17539153.2015.1081012

Published in:

Critical Studies on Terrorism

Document Version:

Peer reviewed version

Queen's University Belfast - Research Portal:

Link to publication record in Queen's University Belfast Research Portal

Publisher rights

(C) 2015, Andrew Thomson

This is an Accepted Manuscript of an article published by Taylor \& Francis in Critical Studies on Terrorism on 07 September 2015 , available online: http://www.tandfonline.com/doi/full/10.1080/17539153.2015.1081012

\section{General rights}

Copyright for the publications made accessible via the Queen's University Belfast Research Portal is retained by the author(s) and / or other copyright owners and it is a condition of accessing these publications that users recognise and abide by the legal requirements associated with these rights.

Take down policy

The Research Portal is Queen's institutional repository that provides access to Queen's research output. Every effort has been made to ensure that content in the Research Portal does not infringe any person's rights, or applicable UK laws. If you discover content in the Research Portal that you believe breaches copyright or violates any law, please contact openaccess@qub.ac.uk. 


\section{State Crime on the Margins of Empire: Rio Tinto, The War on Bougainville and Resistance to}

Mining, by Kristian Lasslett, London, Pluto Press, 2014, 246 pp. (paperback) ISBN: 9780745335049

The island of Bougainville, a region of Papua New Guinea, experienced one of the most violent civil conflicts in the region's history with estimates of up to 20,000 people killed between 1988 and 1997. A central feature of this fighting involved the Papua New Guinean state's protracted counterinsurgent campaign unleashed to pacify unrest, anti-mining movements and secessionist resistance. As part of this campaign, the military and its various appendages subjected many Papua New Guinean citizens to torture, extrajudicial killings, internment, and mass forced displacement amongst other forms of violence. State Crime on the Margins of Empire, Kristian Lasslett's first book, and the first in a new Pluto Press series on state crime, ${ }^{1}$ traces the interplay of social, political, and economic conditions that gave rise to this conflict, concentrating specifically on these state criminal acts of violence. Analysing this recent history through a "classical Marxist" lens, Lasslett presents an extensively detailed and original account of the Bougainville civil war which challenges some of the more conventional interpretations of events on the island as well as approaches to understanding state crime.

As Lasslett states, this book aims to "understand more fully the criminogenic potentialities inherent in actually existing capitalism by applying classical Marxist theory to illuminate... the interplay of forces that underpin the crimes of Empire, as they emerged in the concrete specificity of Bougainville" (p.21). In this sense there are two main objectives in State Crime on the Margins of Empire. First, it seeks to provide a detailed examination of the rise of state crime in Bougainville which situates the conflict within the context of the workings of Empire and capitalist development Lasslett's usage of Empire echoes the work of scholars such as Rosenberg (1994) ${ }^{2}$, who see capital as the organising principle of Empire, rather than a particular state formation. Indeed, this analysis judicially connects a myriad of localised forces, including state actors, to the imperatives of capital. It brings together theories and concepts taken directly from Marx, Trotsky, Foucault and others to examine how the Papuan New Guinean government, with Australian military support, and pro-state paramilitaries worked in concert with the Bougainville Copper Limited, a mining corporation subsidiary of the multinational Rio Tinto, against the Bougainville Revolutionary Army and anti-mining resistance movements. Secondly, in making this analysis, this book aims to make a contribution to state crime scholarship and to the discipline of Criminology more generally. Critically, Lasslett has uncovered a distinctively rich body of primary materials obtained through interviews with senior statecorporate officials, triangulated with internal records from the three central organisational protagonists. This allows him to give a rare 'insider' account that intimately traces the organisation of state criminality through the voices of Ministers, military officials and corporate executives. Using a "classical Marxist" framework to develop this case-based analysis, Lasslett directly critiques established methodologies and theories of state crime, opening new avenues for debate and research.

\footnotetext{
${ }^{1}$ State crime is an interdisciplinary field that argues that states often conduct illicit practices in a range of theatres. The field emerged during the early 1990s and has grown significantly over the past decade. It largely focuses on the mechanisms and motivations that inform different forms of state crime, and the dynamics of social movements that emerge to censure and sanction criminal state actors. Specific attention has also been given to the role corporate actors play in the organisation of state crime, sometimes referred to as statecorporate crime. This assumes a critical focus in Lasslett's volume.

${ }^{2}$ Rosenberg, J. (1994) The Empire of Civil Society: A Critique of the Realist Theory of International Relations. Verso: London.
} 
The book largely manages to complete these two central aims, and quite well. The carefully crafted Marxist framework that Lasslett develops in the opening chapter is more than just a lens used to analyse the descent into state and corporate crime in Bougainville in the subsequent chapters. Here Lasslett explicitly makes the argument that this methodological position can overcome certain limitations to the "empiricist" (positivist) perspectives which have hitherto largely dominated scholarship into state crime. By building on existing Marxist critiques of empiricism, a convincing rationale for an alternative approach to state crime is made. This argument is then further developed in the concluding chapters with much more nuance in which Lasslett not only makes concluding observations regarding the Bougainville case, but also draws out lessons from applying this specific approach, and the broader implications this has. This speaks to the wider applicability of Marxist theories and concepts, but it is aimed at opening debate in state crime scholarship and widening its methodological horizons.

The application of this framework to examine the nexus between capital and state crime in Bougainville, however, represents the main thrust of the book. The author astutely draws from a wide range of theories and concepts, but primarily Marx's theories of value, surplus value and capital, as well as Trotsky's combined and uneven development; he also draws helpfully from Bukharin's prison notebook, Philosophical Arabesque. The appeal to these original thinkers and conceptual tools strengthens the analysis, and Lasslett consistently and explicitly draws the reader's attention back to exactly how these are applied. This provides clear indication of how this "classical Marxist" approach is used. The examination of state crime in Bougainville starts by providing a critical history of colonial Papua New Guinea in which the social arrangements fabricated by imperial domination (and their intersection with local customs and cultures) laid the structural foundations and the specific articulations of capitalist development which ultimately set the stage for conflict. The third chapter focuses on Bougainville Copper Limited, the mining company at the heart of class conflagrations, and its exploitative practices. The chapters that follow detail the gradual build-up from land-owner resistance to mining to a full-blown insurgency against mining operations and ultimately against the Papua New Guinean state that supported them. Yet, as these chapters lucidly demonstrate, statecorporate retaliation in attempts to stabilize the region matched and usually far outpaced that of counter-hegemonic actions. Indeed, chapter five outlines the contours of the Papua New Guinean state's brutal counterinsurgency campaign. This, as the book demonstrates, represented a coercive mechanism of statecraft to preserve the political and economic conditions conducive to capital. Most presciently, this counterinsurgency consisted of extremely violent tactics against innocent civilians and villages, social movements, and, of course, the Bougainville Revolutionary Army. As the analysis shows, the same processes underpinning these outcomes produced other fronts of counter-resistance such as pro-state militias and paramilitary formations as well as various other social dislocations and ruptures. State crime in Bougainville, in Lasslett's analysis, is ultimately a result of localised sociopolitical arrangements present in the context of Empire, along with the imperatives of capital that this entails.

In many ways the account of this descent into state-corporate violence is typical. It is similar to Marxist accounts of the underpinnings of counterinsurgent violence elsewhere and the style of analysis will be familiar to Marxist scholars of state violence. However, the substantial level of research in excavating the social processes and forces at play in determining state-corporate crime is one of the principal strengths of this book and one that sets it apart from previous scholarship. Lasslett introduces a staggering wealth of information gathered from archival work, recently uncovered or 
declassified primary documents, work with the extant literature, and a series of original interviews with some very honest admissions by state functionaries, mine executives, soldiers, as well as some individuals involved in the resistance. The careful presentation of this widely sourced evidence in combination with a meticulous application of theories and concepts provides a compelling and extremely rich account of the processes at work in generating the patterns of state crime that are the ultimate focus of the book. There is a sharp understanding of the relationships between different actors, such as Bougainville Copper Limited's relation with the local Papua New Guinean police, the national military and the Australian government, amongst many others in a tangled web of relations constitutive of this particular form of Empire. You definitely get the sense while reading the book that a good part of the author's life was wrapped up in this project, travelling extensively to attain needed documents and to conduct interviews. Through this commitment and attention to detail, Lasslett has most likely set himself up as one of the experts on the civil conflict that ravaged Bougainville. The book certainly makes a contribution to the large literature on this conflict, not just by challenging existing interpretations of the conflict by established scholars (particularly Anthony Regan), but also by bringing together new information on the conflict's history.

Another strength and refreshing aspect of this work is the unusual focus on this corner of the world. Many studies of its kind almost single-mindedly centre on the predations of major imperial powers, primarily Britain, and more recently in history, the United States of America. Yet this research demonstrates that socially contingent processes of capitalist expansion can potentially have many expressions of violence even in remote areas of the world not immediately central to Empire writ large. Additionally, this book joins other Marxist works in challenging conventional liberal notions that conflict is development in reverse. Instead, it helps to further uncover the often violent underpinnings of the workings of capital. This research, then, represents a contribution to Marxist understandings of such processes more generally.

This does not mean that the book is without its drawbacks. As with any research project there are a few, some of which I mention here. On a basic level, the detail in the Marxist positioning as well as the history and empirical work makes for dense reading. I would imagine that for many readers not already familiar with Marxist jargon or the history of the Bougainville conflict getting through the book would be a bit of a test of concentration. It is certainly not as daunting as many Marxist analyses, but may be so for non-academic readers in particular. On a more scholastic note, while the book is clearly speaking to the field of Criminology and the sub-set of literature on state crime, there is little relation of this work to scholarship on state terrorism or other Marxist-inspired analyses of state violence to which this work clearly makes a contribution. This is not necessarily a major drawback as readers can infer their own connections to other bodies of work, but it is not made clear how this book follows a larger trajectory of scholarship into state violence. Additionally, although I cannot claim to have in-depth knowledge of Criminology and the discipline's expected areas of focus, there seemed to be a surprising lack of reference to international law. The book primarily uncovers conditions conducive to state crime, but international legal structures, statutes, and codes that specific state actions clearly violated are not mentioned. This was an unexpected omission to me given the emphasis on state crime. It is clear there is much more focus on social processes, or non-legal forms of censure, rather than a legalistic focus. The final emphasis on resistance to state crime (the emancipatory element of the Marxist approach) might have served as a basis on which to offer concrete suggestions as to how to strengthen international law or alternatively change these and other international structures, or similarly ways to create norms for improved state behaviour. 
In many respects, this is a pioneering work. It is one of the first studies of its kind to use a state crime lens. The level of detail contained in the analysis sheds new light on the Bougainville civil war. It also provides scope to better understand the relationships that forge state-corporate crime, and why and how they form with such deadly outcomes. Essentially it is an excellently well researched and thoroughly enjoyable read for those interested in the conflict in Bougainville, state crime, and/or Marxist understandings of the violent workings of Empire. 